\title{
A pénzügyi rendszer ellenállóképessége mindenekfelett - de milyen áron?
}

Összefoglaló: A tanulmány célja bemutatni a központi szerződő felek piacon betöltött szerepének fontosságát, kockázatkezelési keretrendszerét, beleértve a garanciaalapok elégtelensége esetén alkalmazandó eszközöket is. Az elemzés leíró, ismertető jellegű, amely az EU-ban múködő központi szerződő felek szabályozói keretrendszerének bemutatása mellett, annak lehetséges hátulütőit is szemlélteti a piac és a szakemberek szemszögéből egyaránt. A tanulmány rámutat arra, hogy minden szereplő közös célja és érdeke egyaránt a központi szerződő fél lábontartása, de a nem megfelelően kialakított tőkekezelés és stratégia gátolhatja ennek megvalósulását. Bár a jogszabályi keretrendszer alkalmazása Európa-szerte megtörtént, finomhangolásuk pedig állandónak mondható, azok hatékonyságát és sokk-ellenállóképességét egy, a piacon bekövetkező komoly negatív esemény fogja alátámasztani vagy megcáfolni.

Kulcsszavak: központi szerződő fél, saját tőke, helyreállitási terv, ösztönzők

JEL-Kódok: E44, G21, G32

D0I: https://doi.org/10.35551/PSZ_2020_4_2

A 2008-ban kirobbant pénzügyi válságot követően a G20-ak vezetői egyetértettek abban a 2009 áprilisában tartott londoni csúcstalálkozójukon, hogy az érvényben lévő rendszer világszerte sebezhető. A szabályozók olyan lépések megvalósításába kezdtek, amelyekkel orvosolhatók az ellentmondások. A keretszabályozással szemben felmerülő legfőbb kétely abban állt, hogy az nem képes megakadályozni az egyensúlytalanságokat és a negatív spilloverhatásokat az egyes vállalatok vagy akár országok között. Ennek eredményeként az elmúlt évtizedben strukturális változtatások sorát vezették be a pénzügyi rendszerben. A közel-

Levelezésie-cim: melinda.szodorai@gmail.com múltban bemutatott szabályozói kezdeményezések fontos prudenciális követelményekre és továbbfejlesztett védelmi szabályokra tettek javaslatot a rendszer erősítése érdekében. A központi szerződő felek (kszf) jelentették az egyik olyan területet, ahol komoly előrelépésre volt szükség. Az új keretszabályozások végrehajtása mellett a kszf-ek is kiemelt jelentőségre tettek szert a pénzügyi világban. Az elmúlt években e terület vált a „nem banki” szegmens domináns intézményévé. A G20-ak vezetői felismerték a kszf-ek által kínált előnyöket a kockázatkezelés területén, így 2009-ben döntés született a standardizált tőzsdén kívüli származékos ügyletek központi elszámolásáról (G20, 2009). Az említett prudenciális követelmények magukra a kszf-ekre is irányadóvá váltak, 
erősítendő a rendszerszintű stabilitást elősegítő ellenállóképességüket. A válság óta globális standardok végrehajtásával igyekeznek biztosítani az ellenállóképességet, melyeket folyamatosan módosítanak és fejlesztenek is.

\section{ÉRTEKEZÉS}

\section{A kszf-ek általános mechanizmusa}

Egy kszf „központi” féllé válik a kereskedők között, vevő lesz az eladónak és eladó a vevőnek. Ezt a folyamatot nevezzük novációnak. A két fél kitettsége - amely egymással szemben megszűnik - így már kizárólag a kszf felé lesz érvényben, amely biztosítást nyújt a kétoldalú nemteljesítési kockázatokkal szemben (Biais et al., 2012). A kszf-ek előnye, hogy a piaci szereplők kereskedési kitettsége bekerül a mérlegükbe, mentesítve a szerződő feleket a többoldalú kockázati kitettségek alól. Csökkentik a piaci szereplők közötti partnerkockázatokat, miközben a többoldalú nettósítás további előnyöket rejt a tagok számára (Lopez, Saeidinezhad, 2017; Cont, Kokholm, 2014). Elliot (2013) szerint a kszf-ek „túl fontosak ahhoz, hogy csödöt mondjanak”, valamint „túlságosan egymásba fonódtak ahhoz, hogy csödöt mondjanak", vagyis a pénzügyi rendszer gerinceként tekinthetünk rájuk. E tulajdonságuk egyben potenciális kockázatot is jelent (Markose et al., 2012; Duffie, Zhu 2011).

\section{A kszf-ekhez kapcsolódó kockázatok}

Jellemzően a klíringtagok nemteljesítése a kszf-ek elsődleges bizonytalansági forrása, amikor egy vagy több klíringtag nem teljesíti a kötelezettségeit. Ebben az esetben a központi szerződő félnek lépéseket kell tennie az ajánlati könyv visszaállítására (Plata, 2017). Ezt rendszerint a vétlen klíringtagok közöt- ti nyitott pozíciók aukciójával érik el (Wendt, 2015). Az ajánlati könyv visszaállításának kudarca esetén kiemelkedő kockázattal szembesülne a teljes rendszer, stresszhelyzetekben pedig még rosszabb hatások érvényesülnének, ami pótlólagos erőforrások felhasználásához vezetne - például a teljesítő tagoknak hozzá kellene járulniuk a garanciaalaphoz (Priem, 2017). A legsérülékenyebb pontokat - beleértve azokat, amelyeknél a kszf-ek rendszerszintü kockázatot válthatnak ki vagy erősíthetnek fel - a likviditási kockázat kialakulása, a stressz átadása, a kockázatáthárítás, az időzítési kockázat, valamint a tájékoztatási és ösztönzési kérdések jelentik (Murphy, 2017; Pirrong, 2014; Hughes, Manning 2015).

A kszf-ek elsődleges feladata és célja a partnerkockázat kezelésének központosítása azokon a pénzügyi piacokon, ahol működnek (Pirrong, 2014). A kszf-ek kockázatainak és rendszerszintű jelentőségének elemzése során számos szerző - így például Cox és Steigerwald (2017), Hughes és Manning (2015), Faruqui et al. (2018) - párhuzamba állítja a bankokkal. Miközben a két különböző típusú pénzügyi intézmény hasonlít egymásra, elengedhetetlen kihangsúlyozni, hogy a kszf-ek nem bankok. A kszf-ek kockázatkezelőként viselkednek - tehát viselik a klíringtagok nemteljesítésének hitel- és likviditási kockázatát -, míg a bankok kockázatvállalók. Berlinger és szerzőtársai (2016) a bankok működésével hasonlítják össze a kszf-ek „sajátosságait”, melyek meghatározzák a kockázatkezelési rendszerüket is. A kszf-ek egyedinek tekinthetők abból a szempontból, hogy nem fizetési rendszerek, letétkezelők, biztosító társaságok, tőzsdei platformok vagy kereskedési platformok, bár „garanciamechanizmusuk" miatt néhány jellemzőjük alapján a biztosításokra hasonlítanak. E garanciamechanizmus magyarázza, hogy egy elszámolóház bevonása nyomán a kszf miért tűnhet biztosítónak - és nem az elszámolt ügyletek őrének: „Miközben mindkettő közveti- 
tö szerepet játszik, a hasonlóságok itt véget is érnek" (Cox, Steigerwald, 2017).

A kockázatcsökkentő mechanizmus pozitív oldala, hogy minden elszámolt ügylet hozzájárul a kitettségek többoldalú nettósításához, csökkentve a kezelendő kockázat mértékét a nem központilag elszámolt ügyletekhez viszonyítva (Duffie, Zhu, 2011). Következésképp, a kszf-ek több ügyletet számolnak el és a piaci folyamatok igazodnak hozzájuk, így jelentőségük és megbízhatóságuk is nő, tehát a rendszerben jelentkező potenciális spilloverhatások megfelelően és időben kezelhetővé válnak. A kockázatok azért erősödnek, mert a kszf nem lesz képes betölteni elsődleges szerepét és nem tudja elnyelni a sokkot, és végül „materializálja” a válsághelyzetet. A likviditáshiány miatt a károk szétterjednek a tágabb rendszerben.

A jelenlegi szabályozói és piaci követelmények nyomán a kszf-ek kifinomult gyakorlatok megvalósításával menedzselik egy vagy több klíringtag nemteljesítését. Mindazonáltal a nemteljesítéstől függetlenül előálló veszteségek (non-default losses, röviden: NDL) is kulcsfontosságúak az ellenállóképesség szempontjából. A Principles for Financial Market Infrastructures (PFMI) standardokat határoz meg az NDL-ek kezeléséhez, egyedi alapelvekkel a jogi, üzleti, befektetési, letéti és müködési kockázatokra vonatkozóan. A jelen tanulmányban nem tárgyaljuk részletesen az NDL-eket, ugyanakkor a szanálási és helyreállítási tervezés kapcsán minimálisan kitérünk rájuk. Lewis és McPartland (2017) hangsúlyozzák, hogy a kszf-ek NDL-ek kezelésére vonatkozó stratégiája befolyásolhatja az elszámolás és a tagok kereskedési tevékenységének költségét, és végső soron hangsúlyeltolódást okozhat az ösztönzőikben.

Béres (2018) szintén a kszf-ek tagadhatlan pozitív hatására hívja fel a figyelmet. A központi értékpapírtárakat és központi szerződo” feleket egyaránt elemzi, és kiemeli, hogy a két infrastruktúra meghatározhatja a pénzügyi és tőkepiacok hatékonyságát, mivel áttételesen a teljes gazdaság teljesítményére hatással vannak.

Az elsődleges cél a kockázatok csökkentése, illetve a pénzügyi rendszer ellenállóképességének erősítése a piaci szereplők tehermentesítésével. A központi szerződő felek csökkentik a partnerkockázatot, miközben felkészülten képesek helytállni „rendkívüli, de valószerű piaci körülmények" között. A kszf-ek azonban nem jelentenek csodaszert, mivel a pénzügyi rendszer válsága esetén ők sem ússzák meg a durva következményeket. Miközben a kszf-ek védelmet nyújtanak az idioszinkratikus partnerkockázattal szemben, valamint a rendszer egésze szempontjából garanciát jelentenek, semmilyen alapvető védelmet nem adnak az aggregált kockázattal szemben; sőt, a kockázatok áthárítását is ösztönözhetik (Biais et al., 2016). Ugyanakkor egy kszf nemteljesítése rendszerszintű kockázattá válik, ami az ellenállóképesség öszszeomlásához - vagy legalábbis érdemi meggyengüléséhez - vezet (Duffie et al., 2015). Három ilyen kiemelt jelentőségü esemény történt 1973 óta, néhány esetben kézzelfogható közelségbe is került (Kiff, 2014). Ezek az árupiacokon következtek be, többnyire azért, mert a váratlan időjárási körülmények keresztülhúztak spekulatív célú ügyleteket. Az átláthatósági és kockázatkezelési eszközök azóta már fejlődtek, de bevetésükre még nem került sor, így hatékonyságuk is bizonytalan.

\section{A szabályozói háttér áttekintése}

Az említett potenciális kockázatok megfelelő kockázatkezelési eszközökkel menedzselhetők, és nem szabad elfelejtenünk azt a szabályozói célt, mely szerint prudens és szigorú jogszabályi háttérrel kell megelőzni az elégtelen kockázatkezelési rendszerek kialakulását. A kszf-kre vonatkozó európai uniós rendelet 2012-ben került kiadásra. Ez az európai piaci infrastruk- 
túra-rendelet (European Market Infrastrucures Regulation, rövidítve: EMIR) nevet viseli. Az EMIR szövegét szabályozói technikai standardok egészítik ki (úgynevezett „technikai részletek”). Összesen 9 szabályozói technikai standard egészíti ki az EMIR-t, míg 3 végrehajtási rendelet segíti annak végrehajtását.

Továbbá kiegészítő iránymutatások is készültek a jogszabály értelmezéséhez és alkalmazásához. Ezenkívül az Európai Értékpapírpiaci Felügyeleti Hatóság (European Securities and Markets Authority ESMA) rendszeresen közzétesz úgynevezett Q\&A-kat (kérdések és válaszok). 2012-ben került sor a pénzügyi infrastruktúrához kapcsolódó ajánlások konszolidálására, és egyúttal megalkották az értékelésükre szolgáló keretrendszert "pénzügyi, piaci infrastruktúrákra vonatkozó alapelvek" (PFMI) néven. A PFMI-ben szereplő ajánlásokat a kszf-ek helyreállítására, stabilitására és átláthatóságára vonatkozó javaslatokkal egészítették ki a későbbiekben. Miközben ugyanazt a célt - vagyis a pénzügyi rendszer egyensúlyát - szolgálják, a PFMI és az EMIR alapvető különbségeket mutat. A legfontosabb eltérés, hogy az EMIR sokkal részletesebben szabályoz. Bár a PFMI-ajánlások 2012 óta fejlődtek, az EMIR még így sem fedi le őket teljesen. $V a ́$ radi (2018) olyan tényezőkre hívja fel a figyelmet, amelyek a PFMI és EMIR közötti szakadék elmúlt évekbeli mélyülését magyarázzák.

A javasolt keretrendszer megfelelő alkalmazása érdekében az ESMA - az illetékes nemzeti hatóságokkal együttműködve - felügyeli a joghatósága alá eső kszf-ek tevékenységét. A helyi hatóságok még szigorúbb szabályokat írhatnak elő. A Magyar Nemzeti Bank látja el Magyarország egyetlen központi szerződő felének (KELER kszf) felügyeletét. Felügyeleti funkciójában a Magyar Nemzeti Bank hatósági eljárásokat köteles folytatni saját feladatkörében, beleértve az engedélyezési eljárásokat, hatósági ellenőrzéseket, valamint a nem megfelelés esetén kivethető szankciókat. A tőkepiaci tör- vény és az EMIR egyidejűleg szabályozzák a KELER kszf által végzett klíringtevékenységet, amelyeknek a kszf köteles folyamatosan megfelelni. A kszf a fizetési rendszer része, vagyis a tőkepiaci törvényen kívül további rendeletek szabályozzák az infrastruktúra technikai működtetését, általános biztonságát, illetve az üzletmenet folytonosságát (MNB, 2009a). A Magyar Nemzeti Bank az átláthatóságot, a garancia szabályait, a kockázatkezelést, a biztosítékkezelést és a díjszabás alapelveit is szabályozza (MNB, 2009b). A Magyar Nemzeti Bank évente értékeli a teljes fizetési rendszert (MNB, 2019).

A különböző szabályok és rendelkezések egy alaposan végiggondolt folyamatban születnek, beépítve a központi szerződő felek elszámolásában szerzett több mint egy évszázados globális tapasztalatot. A következőkben általános jelleggel mutatjuk be azokat a pénzügyi forrásokat, amelyek a kszf-ek rendelkezésére állnak a nemteljesítések kezelésére, különös hangsúlyt fektetve a kszf-ek rendszerben elérhető tőkéjére.

\section{TÖBBLÉPCSŐS VESZTESÉGFEDEZÉS}

A többlépcsős veszteségfedezés jelenti a tagi nemteljesítésre vonatkozó mechanizmus pénzügyi alapját. Kellően nagynak kell lennie ahhoz, hogy biztosítsa a túlélést, valamint megvédje a rendszert a zavaroktól. Az úgynevezett „Cover-2”-szabály értelmében a többlépcsős veszteségfedezés volumenének el kell érnie annak a két klíringtagnak a veszteségeit, amelyek felé a kszf legmagasabb kitettsége fennáll. A klíringtagok és az érintettek egyaránt elvárják a kszf életképességét. A tőkebevonás igénye mindkét oldalon felmerül a rendszerben, így nagy a tét mindenki számára. A jelen tanulmány a kszf-ek által biztosított saját forrásaira összpontosít, miközben a garanciaalap elemeit csak röviden mutatjuk be. 


\section{Árkülönbözeti letét és garanciaalap- hozzájárulás}

A szabályozások elöre meghatározott sorrendet írnak elő az elérhető egyenlegek felhasználására. A letétek jelentik a pénzügyi források első szintjét. Ezeket a kszf-ek kizárólag a nemteljesítö tag veszteségeinek fedezésére használhatják. A vétlen tagok által biztosított letétek nem használhatók a többlépcsős veszteségfedezés igénybevétele során. A letétek elsődleges célja a klíringtagok pozícióiban - normál piaci körülmények között - esetlegesen bekövetkező piaci veszteségek fedezése (41. cikk és VI. fejezet, EMIR). A prociklikusság olyan addicionális tényezőként jelentkezik, amelyet szintén figyelembe kell venni. A magyar kszf által alkalmazott letétszámítási módszertan Váradi és Béli (2017) javaslata alapján készült, a szabályozói követelményekkel teljes összhangban.

A letéteket a második eszköztípus, a garanciaalap-hozzájárulás követi (48. cikk, EMIR). A garanciaalap-hozzájárulások felhasználása stresszhelyzetben történik. A szabályozói elöírások értelmében a központi szerződő feleknek belső keretszabályzatban kell meghatározniuk a rendkívüli, de valószerű piaci körülmények típusait. A rendkívüli piaci körülmények nyomán felmerülő veszteségek fedezésén túl ezen a szinten jelenik meg a klíringtagok közötti veszteségek viszontgaranciája és megosztása is. A vétlen tagok hozzájárulásai is felhasználhatók szükség esetén, de ezt még megelőzi egy harmadik szint bevonása. Ide tartoznak a kszf-ek saját forrásai, vagyis sajáttőke-hozzájárulásai (angol szójátékkal: skin-in-the-game - SITG).

\section{A kszf sajáttőke-hozzájárulása}

Az EMIR 35. cikke értelmében a kszf-ek kötelesek saját tőkéjük jelentős részét rendelkezésre bocsátani a többlépcsős veszteségfedezés rend- szerében (sajáttőke-hozzájárulás). Ennek mértéke 25 százalékban került meghatározásra. A SITG két típusa ismert. Az alapszintű garanciális tooke elvárt szintjét 25 százalékban állapította meg a szabályozó, melynek felhasználása megelőzi a vétlen tagok garanciaalap hozzájárulásainak igénybevételét. $E$ vállalás keretében a kszf menedzsmentje és részvényesei is viselik a következményeket, ha elkerülhetetlen a kszf tőkepufferének mozgósítása (Cont, 2015).

Kutatók (Cont, 2015; Murphy, 2017; McPartland, Lewis, 2017) hangsúlyozzák, hogy a veszteségfedezés keretében elérhető források kimerítése és bizonyított elégtelensége esetén rendelkezésre kell állnia egy további SITG-nek is, az úgynevezett kiegészítő garanciális tőkének (még a helyreállitási szakaszt megelőzően). Ez nem kötelező, de a kszf-ek igénybe vehetik a drasztikusabb helyreállitási eszközök elkerülése érdekében. Azt sugallják, hogy a szabályozók tudják megválaszolni a következő kérdést: milyen mértékủ sajáttőke-hozzájárulás lenne elegendő ahhoz, hogy rendelkezésre álljon az általuk szükségesnek tartott klíring forrás, amennyiben a piaci szereplők szabadon dönthetnének egy adott ügylet elszámolásáról vagy elszámolásának mellőzéséről? Cox (2015) javaslata szerint a felügyelö hatóságoknak „kellene biztositaniuk, hogy megfelelöen objektiv és kiegyensúlyozott döntés szülessen. "Míg az alapszintü garanciális tőke „aukciós ösztönzöként és a kellemetlenségek elkerülésére szolgáló önrészként" müködik, a kiegészítő garanciális tőke „képes pótolni az alapszintü garanciális tökét a közbizalom fenntartása érdekében."

Bár a kszf a „saját bőrét viszi vásárra”, a bevont tőke nem lehet a veszteségek elnyelésének elsődleges forrása, különben jelentősen megváltoztatná a piaci résztvevő ösztönzőit. Cox és Steigerwald (2017) felvázolják, hogy jelentős mennyiségű kszf-tóke miképp tudja megszüntetni a kszf kölcsönös kockázatviselési jellegét, visszatartva a tagokat a nemteljesítő tag 
pozícióinak felszámolását célzó, szükséges folyamat támogatásától, befolyásolva a kszf üzleti modelljét. Mindemellett káros következményekkel járhat, ha a sajáttőke-hozzájárulás mértéke nem illeszkedik a kszf kockázati profiljába, mert túl magas vagy alacsony. Murphy (2017) szerint a kszf veszteségfedezéshez történő elégtelen tőkehozzájárulása esetén a klíringtagok magas kockázatot vállalnának a klíringtevékenység keretében, és olyan ügyleteket keresnének, amelyek nem kerülnek elszámolásra. Túlságosan magas SITG esetén pedig erkölcsi kockázat merülhet fel.

\section{A NAGYMÉRTÉKÜ SAJÁTTŐKE- HOZZÁJÁRULÁS ELLENI ÉRVEK}

A magas SITG bizonytalanul hat az elszámolási tevékenységre. A biztosíték költséges, és egy magasabb tőkekövetelmény miatt a kereskedőknek magasabb biztosítékköltségeket kell viselniük, de egy megfelelően tőkésített kszf ellenállóbb, így a talpon maradó kereskedők nyugodtabbak lehetnek, valamint kisebb - vagy egyenesen nulla - veszteséggel számolhatnak. (CPMI-IOSCO, 2012).

A szabályozók szigorú szabályokat állapítanak meg a kszf-ek számára a veszteségek elnyelése és kölcsönös megosztása érdekében. Nem szabad elfelejtenünk, hogy ez a szint ösztönzi továbbá a kszf-et arra, hogy megfelelő kockázatkezelést alkalmazzon a klíringrendszerében. Saját pénzügyi forrásainak bevonása fegyelmező erőt jelenthet a kszf számára, hogy komolyan vegye a kockázatkezelést, illetve megakadályozza kockázatos pozíciók tömeges felépülését megfelelő biztosíték nélkül. Az átlátható folyamatok és politikák egy kétségkívül ellenálló és sokktűrő rendszert eredményeznek.

A kszf-szakértők mindezekkel tökéletesen ellentétes álláspontot képviselnek a SITG mértékét illetően. A CME kiemeli, hogy „A kszf kockázatvállalása nem védi meg a végső ügyfelet. " Felhívja továbbá a figyelmet arra, hogy a koncentrációs kockázat is megnő. Erősítheti az erkölcsi kockázatot a klíringtagok körében, mivel a kszf-ek jelentősebb pénzügyi forrásokkal járulnak hozzá a garanciaalaphoz. A koncentrációs kockázat kezelésének egyik módja az azt előidéző klíringtag büntetése. Az érintett fél több biztosíték befizetésére kötelezhető, így nemteljesítés esetén az így bevont forrásokból fedezhetők az általa előidézett költségek (Surprise, 2015). Máskülönben a végső ügyfelek is kárvallottak lennének a kszf pénzügyi forrásainak kimerülése esetén. Hoszszú távon ez nem lenne előnyös sem a központi szerződő fél, sem a végső ügyfelek számára, különösen a nemteljesítési események felhalmozódása esetén. A CME álláspontja szerint a végső ügyfél védelmét nem a kszf garanciaalapba történő befektetései biztosítják. „Kipótolhatók vele az ügyfélszámlán elöálló hiányok, ami védelmet biztosit a vétlen végsö ügyfeleknek.” (Surprise, 2015). A szakértők a magas tőkeköltséggel és a klíringtagok ösztönzőivel magyarázzák a nagyarányú sajáttőke-hozzájárulással szembeni szakmai álláspontjukat. Ugyanakkor egyetértenek az alapszintű garanciális tőke alkalmazásával, mivel az jelenti az első védelmi vonalat, így erős ösztönzőként szolgál a megfelelő kockázatkezelési konvenciók előmozdításához a klíringtevékenység során. Carter és Garner (2015) szintén a kockázatkezelés mozgatórugóit elemzi nemteljesítés esetén.

A CCP $12^{1}$ is megállapítja, hogy „A SITG nem tekinthetö jelentös veszteségelnyelési forrásnak." Érvelésük szerint sem a kszf-ek, sem a nemzetközi standardok nem támasztanak olyan követelményt, hogy a SITG a garanciarendszer elengedhetetlen veszteségelnyelési eszköze legyen. Azonban egyetértenek az előzőekben bemutatott összefüggéssel, nevezetesen azzal, hogy a túlságosan magas SITG "gyengiteni fogja a piaci szereplök ösztönzöit a 
nemteljesités menedzselésének folyamatában történö részvételre, mivel figyelembe veszik majd a kszf sajáttöke-hozzájárulását és saját potenciális veszteségmegosztásukat akkor, amikor kialakitják ajánlataikat a nemteljesités menedzselése kapcsán tartott aukción" (CCP12, 2019).

Daly (2015) érvelése szerint a sajáttőkehozzájárulás jelentősége abban áll, hogy a kszfek annak segítségével megakadályozhatják a nagymértékű nemteljesítések bekövetkezését, mivel bőséges forrásokhoz férhetnek hozzá, és „az elszámolóház-hozzájárulások tökéletes kiindulópontot jelentenek ehhez.” A különböző piacok és garanciaalapok 2014-es jelentései azt mutatják, hogy azok a külön kezelt garanciaalapok, amelyek klíringelt kamattal és hitel-nemteljesítési csereügyletekkel dolgoznak, több mint 200 millió dolláros hozzájárulást tettek. Ez a garanciaalap mérlegföösszegének legfeljebb 2,2 százalékátát jelenti. Európában, az EMIR hatálya alatt, a hozzájárulás mértéke a sajáttőkeforrások 25 százaléka, a minimumtőkekövetelmény pedig legalább 7,5 millió euró. Az eltérő számok az európai és az amerikai elszámolóházak pénzügyi helyzetének különbözőségét tükrözik.

McPartland és Lewis (2017) arra a következtetésre jut, hogy - a kszf tulajdonosi struktúrájától függetlenül - „a sajáttőke-hozzájárulásnak elözetesen finanszirozottnak és a megfelelö jegybanknál letétbe helyezettnek kell lennie." Ez a rendszer összes résztvevőjének könnyítést jelent, mivel így a kszf pénzügyi elköteleződése előzetesen finanszírozott formában biztosított, miközben azonnal hozzáférhető még a legkedvezőtlenebb körülmények fennállása esetén is.

A kutatók és szabályozók a kszf-ek összekapcsolódását hangsúlyozzák, és ilyen szempontból a kockázatok különböző joghatóságok alatt működő kszf-eket is érinthetnek egyidejüleg. A kszf-ek egymást átfedő nemzetközi tagságainak lehetősége miatt a spillover-hatásokon túl előfordulhat, hogy egy kszf több társáéhoz hasonló likviditási problémával szembesül egy adott hálózaton belül. Domanski és szerzőtársai (2015) egy ritka és szélsőséges esetet vizsgálnak, amikor egy részt vevő bank képtelen teljesíteni a kötelezettségeit, így szanálásra sőt, csőd bejelentésére - kényszerül, ami a teljes hálózat ellenállóképességére veszélyt jelenthet, beleértve több központi szerződő felet is. Ebben az esetben társadalmi szempontból lényeges kérdések is felmerülhetnek, hiszen egy globális jelentőségű szereplő nemteljesítésének híre terhet jelentene a talpon maradt résztvevők számára.

\section{A TÖBBLÉPCSŐ̋S VESZTESÉGFEDEZÉS ELÉGTELENSÉGE: SZANÁLÁS ÉS HELYREÁLLITTÁS}

A szabályozók elvárják a pénzügyi piaci infrastruktúrától, hogy helytálljon rendkívüli piaci körülmények között is, de a sokkesemény olyan hatalmas lehet, hogy a kszf elözetesen biztosított, lehívható forrásai kimerülnek, és elégtelennek bizonyulnak a veszteségek fedezésére. Egy ilyen rendkívüli helyzet óriási bizonytalanságot okozna, megváltoztatva a mögöttes kitettségek értékét, ami a kapcsolódó piaci és partnerkockázatok emelkedésében öltene testet a rendszer egészét tekintve (Domanski et al., 2015). Pontosan ezért írják elő a szabályozók a kszf-ek számára, hogy folyamatosan biztosítsák klíringszolgáltatásaikat a rendszerszintű stabilitás érdekében, valamint rendelkezzenek kész helyreállítási és szanálási tervvel a rendezett szanálás levezénylése érdekében (CPSS-IOSCO, 2012; CPMI-IOSCO, 2014; FSB, 2014).

\section{Helyreállítási tervezés}

A stratégia- és a garanciaalap összetétele erőteljesen meghatározza a többlépcsős veszteségfedezés rendszerébe bekerülő addicionális forrá- 
sokat, valamint a források elégtelensége esetén alkalmazandó eszközöket. A pénzügyi rendszerek védelme érdekében a kszf utolsó lépésként helyreállítási és szanálási rendszereket állít fel (Cont, 2015).

Peters és Wollny (2018) a felkészülés fontosságát hangsúlyozza. A helyreállítási terv elkészítése kulcsfontosságú eszköz a kritikus szolgáltatások azonosítása érdekében a kszfek és a szabályozó számára egyaránt; emellett stressz-forgatókönyveket is ki kell dolgozni a nemteljesítésre és nemteljesítésen kívüli eseményekre, melyek meggátolhatnák a kszf-et kritikus funkcióinak ellátásában. A kritériumok kvalitatív és kvantitatív szempontjait egyaránt azonosítani kell, hogy a helyreállítási terv és a helyreállítási eszköztár teljesen vagy részlegesen bevethető legyen. A tervnek fel kell vázolnia a kszf számára különböző körülmények között rendelkezésre álló lehetőségeket. Az illetékes felügyelő hatóságnak rendszeres időközönként felül kell vizsgálnia a tervet, valamint értékelnie kell annak megfelelőségét. Jelentős piaci változás, illetve a szabályozói háttér érdemi változása esetén olyan hiányosságok alakulhatnak ki, amelyek miatt a kszf fontolóra veheti a terv végrehajtását. Ez a terv rugalmas megvalósítását igényli. Azonban a felügyeleti beavatkozás korlátozott. A terv végrehajtása a központi szerződő fél kizárólagos feladata. A kszf felé fennálló potenciális kitettség számszerüsítésének megkönnyítése érdekében a szabályozók igyekeznek növelni az átláthatóságot a klíringtagokra gyakorolt hatás helyreállítási tervben történő bemutatásával.

A helyreállítási eszközök szabályozó által elöírt általános keretrendszere a tagok nemteljesítése esetén alkalmazandó eszközöket jelenti, illetve tartalmazza azokat a lépéseket is, amelyeket a veszteségek elosztása során követni kell abban az esetben, ha a veszteségeket nem a tagok nemteljesítése okozta (CPMIIOSCO, 2014). A következőkben ezen eszközöket és jellemzőiket mutatjuk be.

\section{A résztvevök nemteljesitése nyomán elöálló fedezetlen veszteségekhez kapcsolódó eszközök}

KéSZPÉNZBefizetÉsi feLHÍvÁs. Normális körülmények között a kszf-ek előírhatják a vétlen klíringtagok számára többletforrások biztosítását, de kizárólag a nemteljesítés nyomán előálló veszteségek fedezésére. A klíringtagokhoz intézett felhívásoknak arányosnak kell lenniük az előzetesen befizetett nemteljesítési forrásokkal, illetve a klíringtagok által a kszfnél adott napon nyilvántartott pozícióinak aktuális piaci (MTM) értékével. Az átláthatóság növelése, illetve ezzel egyidejűleg az előírt készpénzbefizetés összege körüli bizonytalanság csökkentése érdekében az Európai Parlament több készpénzbefizetési felhívást tesz lehetővé, amelyek számát a szanálási hatóság maximálja.

A cél a vétlen klíringtagokra eső maximális veszteség csökkentése a veszteség megosztásával az egyes tagok kszf-be hozott kockázatának arányában. Ráadásul e megközelítés előzetes ösztönzést jelentene a klíringtagoknak, hogy korlátozott kockázattal érkezzenek a kszf-be (Peters, Wollny, 2018).

A KSZF ÁLTAL LEVONT KIEGÉSZÍTŐ PÉNZÜGYI FEDEZET. Ez egy korlátozott idejű eszköz, melynek a haircut csökkentése is részét képezi minden olyan kiegészítő pénzügyi fedezetnövekmény vagy -nyereség esetében, amely a vétlen tagoknak köszönhetően keletkezik. Minden bruttó vagy nettó követelés, illetve az aktuális piaci érték növekménye is bevonható a haircut-ba. A legnagyobb hátránya, hogy a résztvevők idővel nem lesznek hajlandók befizetni az előírt árkülönbözeti letétet. Ha a központi szerződő fél nem képes gyorsan helyreállítani a klíringtevékenységét, további lépésekre lesz szükség.

Az ÁRKÜLÖNBÖZETI LETÉT FELHASZNÁLÁSA. Ahogy az árkülönbözeti letét felhasználása kap- 
csán bemutattuk, e letét célja a szolgáltató kötelezettségeinek fedezése, és nem használható fel veszteségmegosztási célra. Az árkülönbözeti letét nem áll összefüggésben a kszf fizetésképtelenségével, és helyreállítás vagy fizetésképtelenség esetén sem csökkenthető. A talpon maradó tagok árkülönbözeti letétjének felhasználása esetén kötelesek pótolni az árkülönbözeti letétet, és/vagy olyan szintre kell csökkenteniük a kszf-nél fennálló kitettségüket, hogy a fennmaradó árkülönbözeti letét megfelelő fedezetet nyújtson. A bevezetésre kerülő helyreállítási eszköz tovább erodálhatja a kszf-be vetett bizalmat. Egyúttal prociklikusságot hozna a rendszerbe. A klíringtagok hajlandósága a kszf letétfizetési felhívásának teljesítésére drasztikusan csökkenni fog.

Többen (EACH, 2015; PFMI, 2017) felhívták a figyelmet, hogy rendkívül körültekintően kell eljárni az eszköz használata során! Az elsődleges érv az árkülönbözeti letétek használatának engedélyezése mellett az, hogy jelentős mértékű források állnak a kszf rendelkezésére. Ezzel szembeállítható, hogy ezek kimerítése nyomán elégtelen mértékủ biztosítékot nyújtanának, megnyitva az utat a letétfizetési felhívások felé. ISDA (2013), LCH. Clearnet (2014) és EACH (2015) bemutatják, hogy az eszköz használata miképp vezethet jelentős prociklikus hatásokhoz. Az eszköz komoly nyomást helyezne a klíringtagok likviditására, akár likviditáshiányt is előidézhet, végül pedig a klíringtagok nemteljesítését eredményezheti (Pirrong, 2011).

BizTosítéK És TŐKe BEVONÁsÁvAl JÁRÓ TOvÁвві ЕSZкӧzöк. Ezek az eszközök a központi szerződő fél saját tőkéjét használják, és szükség esetén további tőkebevonást irányoznak elő. Céljuk a nemteljesítésből előálló veszteségek fedezése. Az eszköz a hagyományos többlépcsős veszteségfedezés részét képezheti, és/vagy a helyreállítás keretében is használható.

\section{A fedezetlen likviditáshiány áthidalását célzó eszközök}

LIKVIDITÁS SZERZÉSE RÉSZTVEVŐKTŐL VAGY HARMADIK FÉL INTÉZMÉNYEKTŐL. A kszf-ek megállapodást köthetnek harmadik fél intézményekkel. Ezek az eszközök kevésbé stresszes piaci körülmények esetén hasznosak. Kevésbé megbízható likviditási formát jelentenek, de ha szerepelnek a helyreállítási tervben, akkor további eszközöket is alkalmazni kell a likviditáshiány kezelésére komoly stresszhelyzetekben.

Erre két opció áll rendelkezésre: Azon résztvevők kötelezése értékpapírral fedezett hitel, repó vagy swap nyújtására, akik a kszf felé pénzeszközzel tartoznak. A nyújtandó eszköz értékének összhangban kell állnia a központi szerződő fél felé fennálló kötelezettséggel. A második lehetőség olyan előzetes szabályok alkalmazása, melyek engedélyezik a kszf számára, hogy a résztvevők szélesebb köréből vonjon be likviditást. Míg az első opció előnye, hogy a résztvevőket a kszf kockázatkezelésének nyomonkövetésére ösztönzi, addig a második alternatíva teljesítési kockázathoz vezethet.

\section{A pénzügyi források pótlását célzó eszközök}

Készpénzbefizetési felhívást és feltőkésítést kell alkalmazni.

\section{Az ajánlati könyv visszaállitását célzó eszközök résztvevői nemteljesitést követöen}

SZERZŐdÉSEK KÉNYSZERALlokációja. A kszf először önkéntes és kötelező eszközökkel kísérli meg létrehozni az ajánlati könyvet. A nemteljesítő fennálló kötelezettségeinek kezelése érdekében a központi szerződő fél eladhatja a nemteljesítő pozícióit közvetlen és közvetett résztvevőknek; vásárolhat a nemteljesítő által eladott, de át nem adott eszközöket; illetve a kszf eladhat olyan eszközöket, ame- 
lyeket a nemteljesítő megvásárolt, azonban nem volt képes kifizetni. A kényszerallokáció folyamatában a kszf teljes körüen felosztja a nemteljesítő szerződéseiben szereplő kiegyenlítetlen pozíciókat a résztvevők között. A résztvevők ellentételezésben részesíthetők a szerződések befogadásáért, amennyiben a források engedik.

SZERZŐdÉs MEgSZÜNTETÉSE FELbONTÁsSAL (Teljes, RÉSZleges és Önkéntes). Teljes felbontás esetén valamennyi kiegyenlített és kiegyenlítetlen pozíció megszűnik. Lehetőség van meghatározott pozíciók felbontására is, illetve a résztvevők is megjelölhetik, hogy mely szerződéseket szeretnék megszüntetni. A szerződések számának csökkentésével a kszf kitettsége is mérséklődik az érintett klíringtagok felé, amely így visszaállíthatja az ajánlati könyvet.

\section{A résztvevői nemteljesitéstöl függetlenül elöálló veszteségek (NDL) allokálását célzó eszközök}

TőKE ÉS FELTőKÉsíTÉs. Pótlólagos sajáttőke-bevonás.

BizTOSÍTÁSI VAGY KÁRTALANÍTÁSI MEGÁLLAPODÁsok. A biztosítási vagy kártalanítási megállapodások hatékony eszközt jelenthetnek meghatározott üzleti veszteségek hatásának kezelésére.

EGYÉв ESZкӧzöк. Az előzőekben bemutatott készpénzbefizetési felhívás. A legnehezebb és legnagyobb kihívást azon eszközök meghatározása jelenti, amelyek helyreállítási eszközként kezelhetők. A kiválasztás azért nehéz, mert illeszkedniük kell a központi szerződő fél üzleti modelljébe, kötelezettségi struktúrájába, miközben elengedhetetlen felismerni, hogy néhány biztonsági eszköz már beépült a kszf kockázatkezelésébe.
A szabályozók igyekeznek a lehető legstabilabb együttműködést kiépíteni a kszf-ek között és a teljes pénzügyi rendszeren belül. A megtett lépések minden területen kulcsfontosságúak, és a 2007-2009-es pénzügyi válság óta figyelemreméltó előrelépést sikerült elérni a központi elszámolási tevékenység fejlődése szempontjából. Ugyanakkor a helyreállítási és szanálási eszköztárak iránti igények mögött objektív és prudens szabályozásnak is kell állnia. Egy kszf kudarca azt jelentené, hogy a kockázatkezelési politikák és garanciális eszközök nem voltak kellően prudensek, vagy legalábbis nem teljesítették a veszteség elnyelésére vonatkozó célkitűzésüket.

\section{Szanálási tervezés}

Az ellenállóképesség fejlesztése jelenti a legkritikusabb aspektust. Elsődleges eszközként tekinthetünk a likviditási és koncentrációs kockázati tényezők letétszámítási módszertanokba történő beépítésére, valamint a megfelelő prociklikus pufferek alkalmazására. A kszf sajáttőke-hozzájárulását érdemi szintre kell emelni a többlépcsős veszteségfedezés keretében, ami különösen a profitorientált intézmények szempontjából kulcsfontosságú. A központi szerződő feleknek hatásos nemteljesítés-menedzsment folyamatokkal kell rendelkezniük.

Mindazonáltal az átláthatóságot is növelniük kell értékes, standardizált és auditált közzétételek formájában, melyekben bemutatják a kszf kockázatkezelési módszertanait, visszamérési és stressztesztelési gyakorlatát. A nemteljesítéstől függetlenül előálló veszteségesemények kezelése is kiemelten fontos; e törekvés megnyilvánulásait megfelelő méretű szabályozói tőkekövetelményekkel szükséges támogatni. A többlépcsős veszteségfedezés stabil struktúrája mellett a központi szerződő felek különböző mechanizmusokat működtet- 
nek és szigorú tagsági feltételeket határoznak meg. Továbbá az ellenállóképesség megteremtését segíti a tagok, az elfogadott biztosítékok, illetve a befektetési korlátozások szisztematikus értékelése is.

A helyreállítási terv nagyban függ a kszf által használt többlépcsős veszteségfedezés kialakításától. A helyreállítási terv általános megközelítése szerint a tervnek magát a folyamatot kell elősegítenie, miközben a korábbiakban felsorolt eszközök használata is ajánlott. A listán helyet kaptak előzetesen meghatározott értékelési jogkörök, de kitértünk az előre biztosított kszf-források tőkéjének növelésére, a kiegészítő pénzügyi fedezet növekményének haircut-jára, illetve a szerződések felbontására is.

A hatóságok beavatkoznak a szolgáltatásnyújtás folytonosságának biztosítása érdekében, ha a szanálási terv segítségével nem sikerül elérni a kitűzött helyreállítási szintet. A szanálás olyan eszközökre is kiterjedhet, mint a hatóságok által kötelezően tartalékoltatott előzetes kszf-források.

2019. december 4-én az Európai Tanács álláspontot fogadott el a helyreállításról és szanálásról. A javasolt keretrendszer figyelembe veszi a központi szerződő felek szerepét és rendszerszintű jellegét. Ennek megfelelően a Tanács egy 3-lépéses megközelítést fektet le a nemzeti hatóságok közötti koordináció biztosítása érdekében a szanálási kollégiumok égisze alatt, amelyben helyet kap a megelőzés és felkészülés (a szanálhatóság előtt álló akadályok azonosítása érdekében), az időzítés és beavatkozás (a tömeges károk megakadályozása érdekében), valamint egy szanálási eszköztár (az állami támogatás elkerüléséért).

Plata (2017) a helyreállítási és szanálási terv kszf-eknek kínált védelmét elemzi, és négy alapelvet ajánl a központi szerződő felek figyelmébe a helyreállítási és szanálási rendszer tekintetében: a potenciálisan negatív események rendkívüli jellegének figyelembevétele; az ajánlati könyv visszaállításának jelentősége; ösztönzők; a biztonság és rugalmasság közötti egyensúly fenntartása.

\section{KONKLÚZIÓK}

A kszf-ek fejlesztését az ellenállóképesség és a pénzügyi rendszer stabilitásának biztosítása motiválja. A szabályozók és piaci szereplők közösen dolgoznak a lehető legkiegyensúlyozottabb szabályozói keretrendszer megteremtésén, amely a rendszer erősítése mellett teret enged az erőteljes piaci versenynek is. A kszf többlépcsős veszteségfedezés kialakítására vonatkozó stratégiája hatást gyakorolhat az ösztönzők összehangolására a kszf menedzsmentjének és a klíringtagok szintjén egyaránt. Ahogy a jelen tanulmányban bemutattuk, a központi szerződő felek által létrehozott ösztönzőknek - ideértve a sajáttőke-hozzájárulást a többlépcsős veszteségfedezés keretében - illeszkedniük kell a stratégiához és a kockázatvállalási hajlandósághoz.

A mechanizmus teljes kiszámíthatósága és átláthatósága érdekében véleményünk szerint a kszf-nek akkora mértékü sajáttőke-hozzájárulással kell rendelkeznie a többlépcsős veszteségfedezés rendszerében, amelylyel nem teremt ellentétes ösztönzőket arra, hogy a klíringtagok ne kívánjanak részt venni a nemteljesítő klíringtagok rendszerben tartásában, elkerülve így a piaci stresszhelyzet felerősítését. A tagok és a központi szerződő fél közötti szoros együttműködés a közbizalmat is erősítheti a központosított elszámolásban, ami biztosíthatja a pénzügyi rendszer stabilitását. Az európai tőkepiac soha nem tapasztalta meg a teljes megsemmisülést. Még csak megsemmisülésközeli helyzetben sem volt. Az évek során védelmi vonalak épültek fel a negatív események megelőzése érdekében, de valós körülmények között még nem tesztelték a hatásosságukat. A mechanizmus szigorú ke- 
retrendszerrel rendelkezik, és az elérhető eszközöket a közelgő események intenzitásának megfelelően kell használni. A kszf-ek és a sza- bályozások hatásossága kizárólag a piac által kiélezett negatív helyzetekben nyerhet bizonyítást vagy cáfolatot.

\section{JEGYZET}

${ }^{1}$ A CCP12 egy 37 tagot számláló globális társulás, amelyben minden tag egyenként több mint 50 KSZF-et működtet globálisan az EMEA-régióban, Amerikában, valamint az ázsiai és csendes-óceáni térségben.

\section{IRODALOM}

BÉRES D. (2018). Az értékpapír-kereskedés utáni infrastruktúra - múlt, jelen és jövő. Pénzügyi Szemle, 2018/4, 575-588. oldal, https://www. penzugyiszemle.hu/penzugyi-szemle-folyoiratarchivalt-cikkek/az-ertekpapir-kereskedes-utaniinfrastruktura-mult-jelen-es-jovo

Berlinger E., Dömötör B., Illés F., Váradi K. (2016). Stress indicator for clearing houses. Central European Business Review, 4

Biais, B., Heider, F., Hoerova, M. (2012). Clearing, Counterparty Risk, and Aggregate Risk. IMF, Economic Review, 60(2), pp. 193-222

Biais, B., Heider, F., Hoerova, M. (2016). Risk-Sharing or Risk-Taking? Counterparty Risk, Incentives, and Margins. The Journal of Finance, 71(4), pp. 1669-1698, https://doi.org/10.1111/jofi.12396

Cont, R., Koкholm, T. (2015). Central Clearing of OTC Derivatives: Bilateral vs multilateral netting. Statistical Risk Modeling, 31(1), pp. 3-22, https://doi.org/DOI 10.1515/strm-2013-1161

Cox, R. T., Steigerwald, R. S. (2017). A CCP is a CCP is a CCP. Federal Reserve Bank of Chicago. Policy Discussion Paper, PDP2017-01, https:// www.chicagofed.org/ /media/publications/policydiscussion-papers/2017/pdp-2017-01-pdf.pdf.

Daly, R. (2015). Do CCPs Need More Skin in the Game? Traders Magazine, May

Domanski, D., Gambacorta, L., Picillo, C. (2015). Central clearing: Trends and Current Issues, accessed 13 May, 2018 at BIS Qaterly Rewiew, www. bis.org/publ/qtrpdf/r_q1512g.pdf

Duffie, D. (2015). Resolution of Failing Central Counterparties, in Kenneth E. Scott, Thomas H. Jackson \& John B. Taylor, Making Failure Feasible, How Bankruptcy Reform Can End "Too Big to Fail”. Stanford, CA: Hoover Institution Press, Working paper, http://www.darrellduffie.com/ uploads/working/DuffieCCP-ResolutionJan2015. pdf

Duffie, D., Zhu, H. (2011). Does a Central Clearing Counterparty Reduce Counterparty Risk? The Review of Asset Pricing Studies, 1(1), pp. 74-95, https://doi.org/10.1093/rapstu/rar001

Elliot, D. (2013). Central counterparty loss allocation rules. Bank of England, Financial Stability Paper, No. 20, pp. 1-16 
Faruqui, U., Huang, W., Takáts, E. (2018). Clearing risks in OTC derivatives markets: The CCP-bank nexus. BIS Quarterly Review, pp. 73-90

Hughes, D., Manning, M. (2015). "CCPs and banks: different risks, different regulations”. Reserve Bank of Australia Bulletin, pp. 67-79

KIFF, J. (2019). History of Central Counterparty Failures and Near-Failures. The OTC Space. https:// www.theotcspace.com/content/history-centralcounterparty-failures-and-near-failures-derivativeprimer-7

Lopez, C., Saeidinezhad, E. (2017). Central Counterparties Help, But Do Not Assure Financial Stability. Munich Personal RePEc Archive, 80358. https://mpra.ub.uni-muenchen.de/80358/

Markose, S., Giansante, S., Shaghaghi, A. (2012). Too interconnected to fail", Financial network of US CDS Market: Topological fragility and systemic risk. Journal of Economic Behavior and Organization, 83(3), pp. 627-646

McPartland, J., Lewis, R. (2017). The Goldilocks problem: How to get incentives and default waterfalls "just right." Economic Perspectives, Federal Reserve Bank of Chicago, 1

Murphy, D. (2017). I've got you under my skin: Large central counterparty financial resources and the incentives they create. Journal of Financial Market Infrastructures, 5(3), pp. 54-74, https://doi.org/DOI: 10.21314/JFMI.2017.073

Pirrong, C. (2011). The economics of central clearing: theory and practice. ISDA discussion paper series, No. 1, pp. 1-44

Pirrong, C. (2014). A Bill of Goods: CCPs and Systemic Risk. Journal of Financial Market Infrastructures, 2(4), pp. 55-85
Plata, R. (2017). Recovery and resolution regimes for CCPs: Making financial markets resilient to the most extreme events. Journal of Securities Operations \& Custody, 9(2), pp. 98-105

Priem, R. (2018). CCP recovery and resolution: preventing a financial catastrophe, Journal of Financial Regulation and Compliance, Vol. 26 Issue: 3, pp. 351-364,

https://doi.org/10.1108/ JFRC-03-2017-0032

Surprise, G. (2015). Skin in the game doesn't protect end client, CME says. Global Capital, 3/9, p. 106

VÁradi K. (2018). A critique of the regulation of guarantee systems operated by central counterparties. (A központi szerződő felek garanciarendszer szabályozásának kritikája) Economy and Finance, 2(5)

VÁrAdi K., BÉli M. (2017). Alapletét meghatározásának lehetséges módszertana. Financial and Economic Review, 16(2)

Wendt, Froukelien (2015). Central Counterparties: Addressing their Too Important to Fail Nature. IMF Working Papers. 15. $10.5089 / 9781475572933.001$

Capital Market Act, 2001. évi CXX. törvény a tőkepiacról

CCP BEST PRACTICES. (2019). A CCP12 POSITION PAPER. https://ccp12.org/wpcontent/uploads/2019/05/CCP-Best-Practices_ CCP12_Position_Paper.pdf

CPMI-IOSCO (2012). Principles for financial market infrastructures, April

CPMI-IOSCO (2014). Recovery of financial market infrastructures, October 
EMIR - European Market Infrastructure Regulation: Regulation (EU) No 648/2012 of the European Parliament and of the Council of 4 July 2012 on the OTC derivatives, central counterparties and trade repositories (EMIR - European Market Infrastructure Regulation). http://eur-lex.europa. eu/legal-content/EN/TXT/PDF/?uri=CELEX:32 012R0648\&from=EN, downloaded: 8 February 2019

ESMA (2012). European Securities and Markets Authority, Consultation Paper on AntiProcyclicality Margin Measures. Available: https:// www.esma.europa.eu/press-news/esma-news/esmaconsults-ccp-anti-procyclicality-margin-measures, downloaded: 8 January 2020

FSB (2014). Key attributes of effective resolution regimes for financial institutions, Octo ber

ISDA (2013). "CCP loss allocation at the end of the waterfall", available at: https://www2.isda.org/...
==/CCP_loss_allocation_waterfall_0807 (accessed 19 February 2019)

LCH. Clearnet (2014). "Recovery and resolution: a framework for CCPs", available at: www.lch.com/ documents/731485/762444/-and-resolution-aframework-for-ccps.pdf/ (accessed 10 February 2019)

MNB (2009a). 35/2009. (XII. 28.) MNB rendelet a fizetési rendszer működtetésére vonatkozó tárgyi, technikai, biztonsági és üzletmenet-folytonossági követelményekről

MNB (2009b). 11/2009. (II. 27.) MNB rendelet a tőkepiacról szóló törvény szerinti központi szerződő fél tevékenységet végző szervezet szabályzataira vonatkozó követelményekről

MNB (2019). Report on the Payment System (Fizetési rendszer jelentés), https://www.mnb. hu/letoltes/fizetesi-rendszer-jelentes-2019-hunvegleges.pdf 